\title{
歯肉剝離搔爬手術後の新付着に関する研究
}

一脱灰搔爬セメント質に対する歯肉付着について一

\author{
山口十紀夫 \\ 大阪歯科大学歯周病学講座 \\ (指導 : 山岡 昭教授) \\ (平成元年 9 月 4 日受付)
}

\section{Study on New Gingival Tissue Attachment Following Flap Surgery \\ - Gingival Attachment to Cementum in Curettage of the Superficial Layer Following the Use of Citric Acid -}

\section{Tokio YAMAGUCHI}

Department of Periodontology, Osaka Dental University

(Director : Prof. Akira YAMAOKA)

Since endotoxin may be absorbed only in the superficial layer of cementum leaving the deep cementum unchanged morphologically, the cementum of teeth with periodontal involvement was examined. The author considered that the application of citric acid after curetting of only the superficial cementum was better root treatment than complete removal of the cementum. The aim of this study was to examine histological events during the formation of new fibrous attachment to demineralized ce- mentum after flap surgery following citric acid treatment in fifteen dogs. The demineralized cementum prevented the apical proliferation of junctional epithelium. The fibroblasts apposed to the exposed cemental collagen produced numerous new fibrils. Fur thermore, the newly-formed collagen fibrils appeared to link with the exposed ones. These findings suggest that this root treatment would facilitate the formation of new fibrous attachment.

Key words : Curetted cementum, Citric acid conditioning, Diseased cementum, New attachment, Flap surgery

要旨 : 近年, 露出セメント質深層へのエンドトキシン浸透の疑問視や深層セメント質は形態的にはほとんど変化し ていないことなどから, 歯周疾患歯セメント質の取り扱いに再検討の機運がみられる。そこで本研究では, 歯肉剝離 搔爬手術後の新生歯肉に対して, より為害性のない適切な根面を提供するため, セメント質は表層だけの搔爬にとど め, その後クエン酸を塗布した根面状況に対する歯肉付着様式を組織学的に検索した。

実験動物には雑種成犬 15 頭を用い, 術後 1, 2, 3 週に光顕的, 電顕的に観察した。その結果, クエン酸塗布例では, 付着上皮の下方増殖はほとんど認められなかった。脱灰セメント質には, 細胞が密に平行に配列していたが, 脱灰セ メント質線維と細胞間には，新生コラーゲン線維の形成がみられ，さらに，新生コラーゲン線維と脱灰セメント質コ ラーゲン線維との interdigitation が認められた。これらの所見より，セメント質表層を搔爬後，クエン酸塗布を施 
した根面処理法によって, 線維性付着を早期に確立するためのより適切な根面状況が得られることが示された。

索引用語 : 搔爬セメント質, 酸処理法, 污染 (病的) セメント質, 新付着, 歯肉剝離搔爬手術

\section{緒言}

歯周ポケットという特殊な環境にさらされたセメント 質は, 構造的並びに物理, 化学, 生物学的にも変化をこ うむると報告されている ${ }^{1 \sim 5)}$ 。従って, 歯肉剝離搔爬手術 を施す際，このポケット対応セメント質の徹底除去が， 手術の成否を左右する最重要操作として認識されてい $る^{6 \sim 8)}$ 。しかし最近，この歯周疾患歯セメント質の取り扱 いに再検討の機運がみられる。その理由として, (1) 滑沢 化した象牙質面には，新生セメント質の形成は根尖側の ごく一部に限られる ${ }^{9,10)}$,(2) セメント質深層へのエンド トキシン浸透の疑問視 ${ }^{11 \sim 15)}$ ，(3) 深層セメント質は形態 的にはほとんど変化していない ${ }^{16)},(4)$ セメント質保存は 線維性付着を容易に再確立せしめる可能性が高い ${ }^{17,18)}$, などのことがあげられている。

このよ5な背景から，先に西村ら ${ }^{19)}$ は，ヒト歯周疾患 歯に対して，従来のようにセメント質すべてを搔爬する のではなく, 表層のみの搔爬にとどめ, 残存セメント質 面への歯肉付着様式の検索を試み, その結果, かなりの
歯冠側部まで結合組織付着の獲得をみている。半面，こ の搔爬セメント質面に集積した細胞には，小器官の発達 の悪いいわゆる resting phase の細胞もみられたことか ら, 今後, この根面状況に対して治癒がどのように進行 するかについては予断を許さないとも述べている。この ような所見を呈する原因の一つとして，やはりエンドト キシンが, 疾患歯によってはセメント質深層へ浸透して いる可能性も考えられ, これに対処する適切な処理が必 要な場合もあると思われる。そこで著者は, 新生歯肉 に, より為害性のない適切な根面を提供するため, セメ ント質は表層だけ搔爬，その後エンドトキシンを除去す るためクエン酸を塗布 ${ }^{20,21)} し$, この根面状況に対する歯 肉付着様式を超微構造学的に検索した。

\section{材料および方法}

実験動物として, 内国産雑種 成 犬 15 頭（体 重 9.3 $15.6 \mathrm{~kg}$ ）を用い，上下顎左右犬歯部を実験部位とした。 術前処置として, 実験 1 カ月前に動物用ケタラール $50 ®$ (三共株式会社製, 東京) $0.1 \sim 0.2 \mathrm{ml} / \mathrm{kg}$ 筋肉内注射麻

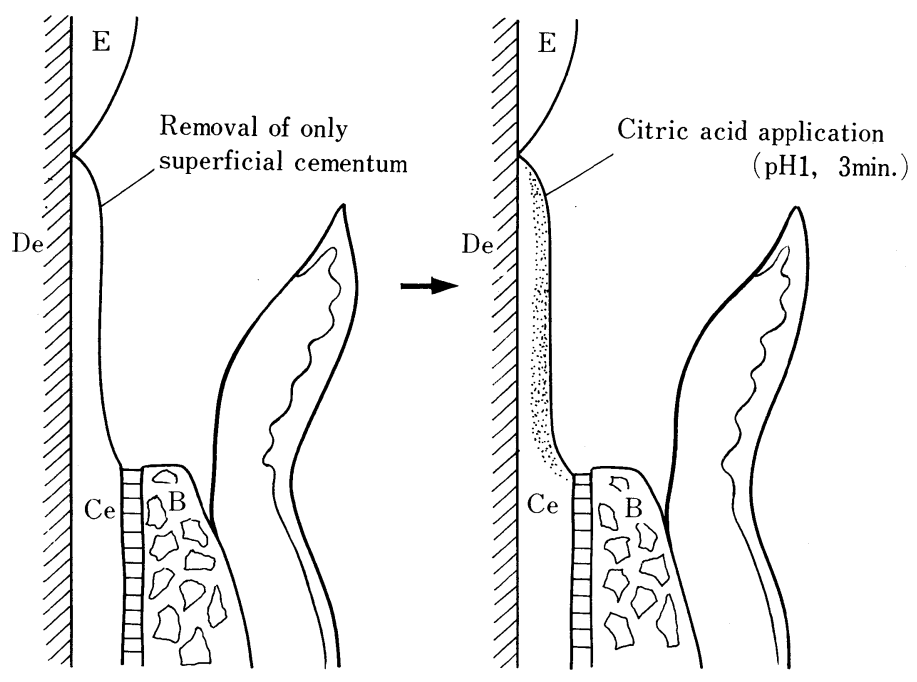

Fig. 1 The schematic drawing illustrates the root treatment used in this study. After removal of only the superficial cementum (Left), the root surface was treated with

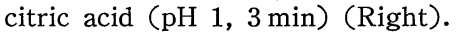


酔下でスケーリングを行った。その後, 可及的に歯肉の 健康状態を維持する為, 同様な麻酔条件下で, 週 1 回の ブラッシングを施した。

実験方法としては, ケタラール筋肉内注射とソムノペ ンチル® (Pitman Moore社製, U.S.A.) $0.5 \mathrm{ml} / \mathrm{kg}$ 腹腔 内注射で完全麻酔した後, 実験部歯肉弁を切開剝離, 歯 槽骨を骨縁から根尖方向に約 $5 \mathrm{~mm}$ 除去した。根面処理 として, 左側上下顎犬歯は, 深層セメント質を残すよう に表層セメント質のみをスケーラーで搔爬, 次いで $\mathrm{pH} 1$ のクエン酸で搔爬セメント質を 3 分間脱灰した (Fig. 1)。

一方，右側上下顎犬歯は，表層セメント質の搔爬のみ で, クエン酸叙布を行わなかった。これらの根面処理 後, 歯肉弁を元の位置に戻し縫合した。術後 $1,2,3$ 週 に屠殺，カコジル酸ナトリウム緩衝 $2.5 \%$ グルタールア ルデヒド $-2.0 \%$ パラホルムアルデヒド混合液にて灌流 固定。続いて, 術部の歯, 歯肉および骨を一塊として採 取, 歯中央部にて割断した。

割断試料の半分は, モース氏の液で脱灰, 型通りの方 法で光顕切片を作成, ヘマトキシリン・エオジン染色を 施し, 鏡検した。他の半分は, カコジル酸ナトリウム緩 衝 $2.5 \%$ グルタールアルデヒド $-2.0 \%$ パラホルムアル デヒド混合固定液 $(\mathrm{pH} 7.2)$ にて $4^{\circ} \mathrm{C}$ で 72 時間, 前固 定した。試料は前固定開始 12 時間後にできるだけ小さ くトリミングを行った。

前固定終了後，カコジル酸ナトリウム緩衝液で一晚浸 漬し, その後, カコジル酸ナトリウム緩衝 $1 \%$ オスミウ

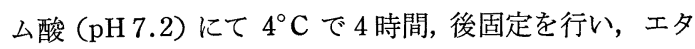
ノール系列にて脱水, Luft 法に従って Poly Bed 812 (Polysciences 社製, U.S.A.) に包埋した。包埋した未脱 灰試料は，歯冠側部と根尖側部とに 2 分割した。各々の 試料は，まず，ダイヤモンドナイフを装着したPorterBlum MT II B 型超ミクロトームで, 約 $1 \mu \mathrm{m}$ 厚さの半 超薄切片を作成, メチレン青で染色して, 光顕的に観 察, 撮影した。その後, 光顕所見の一般的, ならびに特 徵的な部位の超薄切片を作成, 酶酸ウラニールとクエン 酸鉛の重染色を施し, HITACHI H-800 透過型電子顕微 鏡 (加速電圧 $100 \mathrm{kV}$ ) にて観察, 撮影した。

\section{結果}

セメント質表層搔爬後クエン酸塗布例術後 1 週では, 付着上皮対応部結合組織に軽度の炎症性細胞浸潤, 上皮 突起の側方への伸展が認められたが，付着上皮はセメン 卜・エナメル境上部に位置し, 上皮の深行増殖はみられ
なかった (Fig. 2-a)。上皮付着直下部では, 異なる染色 性を示す脱灰セメント質と剝離歯肉弁間に肉芽組織を介 した付着がみられた (Fig. 2-b)。この上皮付着直下の 電顕所見では, 脱灰露出セメント質線維に inactive な 線維芽細胞が近接する像を示したが，この細胞と露出セ メント質線維間にはほとんど新生線維様物質の介在は認 められなかった (Fig. 2-c)。より根尖側部の光顕所見で は, 細胞成分に富む肉芽組織が脱灰セメント質に接し,こ こでは細胞自身が露出セメント質線維間に進入する像も みられた (Fig. 2-d)。電顕的には, euchromatic な核, 発達した r-ER, リボゾームを有した細胞が, 細胞外に活 発な線維様物質の形成を行い, この細胞と露出線維間に 線維様物質の介在がみられた (Fig. 2-e)。

術後 2 週では, 週 1 回の少ないブラッシングの影響に よるものと思われるが, 上皮付着部直下には軽度の炎症 性細胞浸潤が認められ，ほとんど脱灰されていないセメ ント質面に沿って上皮の深行増殖が認められた。しか し, その増殖は完全脱灰セメント質部の最歯冠側部でと どまっていた (Fig. 3-a)。付着上皮下では, 介在する肉 芽組織は, 1 週に比べてより線維化し, 新旧歯肉組織の 区別がつきにくくなっていた。脱灰セメント質には, 細 胞が密に平行な配列をしていた (Fig. 3-b)。電顕像で は，それらが伸展して根面に近接していたが, 露出セメ ント質とその細胞間には典型的な周期構造を有するコラ 一ゲン線維が形成され, 加えて, 一部, 新生線維は脱灰 露出セメント質線維内に進入する像を呈していた（Fig. 3-c-i, 3-c-ii)。他方, クエン酸処理を施さなかった表層. 搔爬セメント質においては, 術後 1 週でみられた歯冠側 部の上皮の位置が術後 2 週例でもクエン酸塗布例と同 様, かなり歯冠側に位置していた (Fig. 4-a)。さらに新 生線維はセメント質面へ垂直に付着し，この週ですでに 本来の付着様式が再確立されていた (Fig. 4-b)。

クエン酸塗布例術後 3 週では, 1,2 週に比べて露出セ メント質線維とそれに近接する細胞間には, より多くの 新生線維の介在がみられた。また, 脱灰露出セメント質 線維と新生線維が交錯している部分も多くみられ，interdigitation が確立されつつあった (Fig. 5)。

\section{考察}

歯肉剝離搔爬手術後の付着を考える際, 軟組織側の対 応の重要性は勿論のこと, 根面性状がその付着成就に大 きく関与することが知られている。現在行われている一 般的な根面処理法は，七メント質を全て除去，象牙質新 
生面を露出させる方法である。これはポケットの形成に 伴って口腔内環境に曝されたセメント質が，エンドトキ シンの浸透をはじめとして種々の変化をこらむっている と考えられることからである。しかし，このセメント質 が全て除去されて滑沢化された象牙質面には, 新生セ义 ント質の形成が根尖側のごく一部にしか認められないこ $と^{9,10)}$ から, 近年, 他の有効な根面性状の検索に力が注 がれている。その一つに，象牙質面へのクエン酸塗布が ある。周知のように，これは象牙質面を脱灰することに より，象牙質コラーゲン線維を露出せしめ，それらと新 生歯肉線維との結合を目的とした根面処理法である。し かし, この方法に対する現在の評価は, 動物実験, 特に 犬を研究対象動物とした場合には良好な結果が得られて いるものの，ヒトへの臨床応用では，その成否が相半ば し，むしろ新旧線維の新結合獲得は余り期待できないと いうのが現状である17,18,22 299。

他方, 西村ら ${ }^{30}$ は, セメント質保存を前提に, セメン 卜質の搔爬は，種々の変化，侵襲をこうむっている表層 セメント質にとどめ，深層セメント質は残存させ，その 残存セメント質に対する付着を検索している。その結 果, この根面状況では, 術後早期に集積した細胞が, 新 生コラーゲンを産生し, 良好な付着が確立すると報告し ている。

本実験においても，表層搔爬にとどめたセメント質に は，術後 2 週で，セメント質面に対して垂直的な封入を 伴った線維性付着が再確立された。この所見は, 本研究 の主目的である脱灰露出セメント質線維と新生歯肉線維 との linkage に比べても，より早く理想的な付着がなさ れており，西村ら ${ }^{30)}$ の結果を再確認した。このように健 全歯の場合, 表層搔爬セメント質に対する歯肉線維付着 は，歯根面に歯根膜線維の残存した場合の根面状況に比 べても，遜色のない速さをもって付着結合が回復され る。

半面，冒頭にも述べたように，この根面操作を七ト歯 周疾患歯に施した際, サル健全歯搔爬セメント質にみら れたよらな良好な治痖様式はとらず，上皮付着部直下に 炎症性反応がみられた ${ }^{19}$ 。この原因として，術後ペリオ ドンタルパック下に沈着したプラーク，あるいは表層セ メント質の不完全な搔爬によるものとも考えられるが, 従来からの指摘にもあるように，ある部位ではエンドト キシンが深層セメント質に浸透し，それが抗原として作 用したのかもしれない。事実, 疾患歯セメント質でのエ ンドトキシンや細菌の侵襲範囲については，現在なお， 意見の対立がある。
本実験の実験目的は，エンドトキシンが深層セメント 質へ浸透した場合を想定し，クエン酸の持つもう 1 つの 作用いわゆる解毒作用を利用すること年,21) と，他方，酸 処理するとはいえ，セメント質そのものの保存を図り たいといら考えからである。従来から，七メント質全層 を除去した象牙質面へのクエン酸㓌布に関する報告は多 数みられる。この根面処理に対する効果は, Ririe ら ${ }^{26)}$ がイヌを用いて行った実験では，実験 7 日目で露出コラ ーゲンと新生コラーゲンの interdigitation を報告して いる。しかし，サルを用いて同様の根面処理を行った西 村らの報告31)では, 術後 10 日目でも, interdigitation は認められず, 露出線維対応創傷部は, なお線維組織と して organization のみられない肉芽組織によって占め られていた。一方，この根面処理に対しては，Ririeら ${ }^{26)}$ と同様，良好な付着結果を報告するものもみられるが， 総じて, interdigitation を認めなかった報告が多い。す なわち, interdigitation という付着様式はとらず，根面 の広範囲な吸收あるいは ankylosis を呈したという 報 告32 34)がそれらである。

脱灰セメント質に対する付着研究は，セメント質露出 コラーゲンと培養線維芽細胞との interaction を観察し

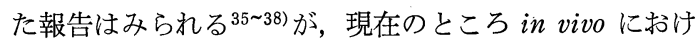
る検索は施されていない。わずかに, root planing 時に 偶然取り残したセメント質にクエン酸塗布がなされ，そ れに対する付着観察があるにすぎない18,23)。クエン酸脱 灰露出セメント質線維に対する本実験結果では, 術後 1 週で，細胞成分に富む肉芽組織による修復がみられ，電 顕的にも，セメント芽細胞と考えられる細胞が露出線維 上に集積し，それらが活発な細胞外基質産生を行ってい た。

この新生細胞の，セメント質露出コラーゲンに対する 明らかに良好な付着形成は，一体何に起因するのである うか。以下の様な要因が関与すると著者は推測する。

（1）セメント質には，その位置的関係から，歯根膜線 維, 歯肉線維が埋入している。従って，コラーゲンのタ イプといら点から考えると，セメント質のコラーダンタ イプは，新生封入線維のコラーゲンタイプと遺伝子的に 同一か，または非常に類似しているコラーゲンを含んで いる可能性がある。

(2) 象牙質とセメント質では石灰化の程度が異なり, セメント質の方が石灰化度が低い。このことは，セメン 卜質コラーゲンが象牙質コラーゲンに比べて容易に露出 してくることを意味する。換言すれば，石灰化度の低い セメント質では脱灰が迅速に行われるので, 露出してく 
るコラーゲンは酸による変性作用をほとんど受けていな いのかもしれない。また, 現在のところ何ら証明はなさ れていないが, このセメント質コラーゲンは, 酸に対 して, 象牙質コラーゲンより抵抗性を有しているのかも 知れない。以上挙げた可能性は, 露出セメント質コラー ゲンが，コラーゲンとしての基本分子構造である crosslinkage を保持するとともに，そのコラーゲンのタイプ の同一性は, 新生コラーゲンとの結合を促進せしめるも のと思われる。すなわち, 歯根膜線維が根面に残存した 場合と類似した治療様式をとるものと思われる。

(3) 象牙質露出線維とセメント質露出線維とでは線維 密度が違う。すなわち前者は高く, 後者は低い。この差 異が細胞の集積に何等かの影響を与えるかもしれない。 事実, 本組織所見が示したように, セメント質線維間に は細胞の進入がみられ，この状態が細胞にとって好適な 線維密度であるのかもしれない。ただ，この細胞がセメ ント芽細胞化するのでなく, 破歯細胞化する可能性もあ るが，本実験では観察し得なかった。

(4) 脱灰露出セメント質コラーグン間基質物 質の方 が，脱灰露出象牙質コラーゲンのそれよりも集積する細 胞の蛋白合成を賦活するのか，または，七メント質基質 には, 象牙質基質には含まれない何か未知の特異的物質 が存在するのかもしれない。Nishimura ら $^{39}$ は脱灰セメ ント質, 脱灰象牙質をはじめとして歯牙各物質の細胞に 対しての chemoattractant を検索しているが, 彼らの 結果では, 脱灰セメント質, 脱灰象牙質ともかなりの chemoattractant を示したが，両者間には差異を認めな かった。

一方, Somerman ら ${ }^{40 \sim 43)}$ は歯の各組織からの抽出物が 細胞の DNA 活性にどのような影響を与えるかを検索し たところ, 象牙質抽出物に比べセメント質抽出物に有意 の数値を認め, セメント質基質物質が細胞の蛋白合成に 影響を与えることを示している。このことは, 象牙質, セ メント質露出コラーゲンは, 兩者とも細胞に対して誘因 力を有するが，ひきよせた細胞をセメント芽細胞化させ る能力は, 脱灰露出セメント質にしか存在しないのか, または脱灰露出セメント質では強いことを示している。

以上のことから, 脱灰露出セメント質線維は脱灰露出 象牙質線維に比へてて, 近接する細胞に活発な細胞外基質 線維合成を行わしめ, ひいては, 早期に新生歯肉線維と の interdigitation へ移行せしめるものと考えられる。

\section{結 語}

現在考えられる歯周疾患歯セメント質の不利益を最大 限除去出来るとみなされる根面処理法, すなわち, セメ ント質表層を搔爬，加えてクエン酸塗布を施した根面と 新生歯肉の付着機構を組織学的に検索した。その結果, この根面処理法によって, 線維性付着を早期に確立する ためのより適切な根面状況が得られることが示された。

\section{謝 辞}

稿を終るにあたり，ご懇篤なご指導とご校閲を賜った山岡 昭 教授に深甚の謝意を表します。

また, 本研究に際し, ご教示をいただいた西村和晃講師, 野 口吉廣助手をはじめ，ご協力くださった教室員各位に感謝いた します。

\section{文献}

1) Armitage, G.C. and Christie, T.M. : Structural changes in exposed human cementum. II. Electron microscopic observations. J. Periodont. Res., 8 : 356-365, 1973.

2) Stahl, S.S. : The nature of healthy and diseased root surfaces. J. Periodontol., $46: 156-161$, 1975.

3) Emslie, R.D. : Some considerations on the role of cementum in periodontal disease. J. Clin. Periodontol., 5 : 1-12, 1978.

4) Wirthlin, M.R., Pederson, E.D., Hancock, E.B., Lamberts, B.L. and Leonard, E.P. : The hypermineralization of diseased root surfaces. J. Periodontol., 50 : 125-127, 1979.

5）長谷川絋司 : 歯周病変によるセメント質の変化と 臨床的対応. 紫耀 (東京都歯科医師会雑誌), 30 : 1-19, 1982.

6) Garrett, J.S. : Root planing : A perspective. J. Periodontol., 48 : 553-557, 1977.

7) Jones, W.A. and O'Leary, T.J. : The effectiveness of in vivo root planing in removing bacterial endotoxin from the roots of periodontally involved teeth. J. Periodontol., $49: 337-342$, 1978.

8) Nishimine, D. and O'Leary, T.J. : Hand instru- 
mentation versus ultrasonics in the removal of endotoxins from root surfaces. J. Periodontol., $50: 345-349,1979$.

9) Listgarten, M.A. : Electron microscopic study of the junction between surgically denuded root surfaces and regenerated periodontal tissues. J. Periodont. Res., 7 : 68-90, 1972.

10）野口吉廣 : 歯肉剝離掻爬手術後の歯肉の付着に関 する超微構造学的研究. 一外科的に象牙質を裸出 させた根面に対する剝離歯肉弁の付着につい て一. 日歯周誌, $26: 21-48,1984$.

11) Everhart, D.L., Dahab, O., Wolff, L. and Stahl, S.S. : The further localization of antibody on cemental tissue. J. Periodontol., 53 : 168-171, 1982,

12) Nakib, N.M., Bissada, N.F., Simmelink, J.W. and Goldstine, S.N. : Endotoxin penetration into root cementum of periodontally healthy and diseased human teeth. J. Periodontol., $53: 368-378,1987$.

13) Eide, B., Lie, T. and Selvig, K.A. : Surface coatings on dental cementum incident to periodontal disease. I. A scanning electron microscopic study. J. Clin. Periodontol., 10 : 157171, 1983.

14) Eide, B., Lie, T. and Selvig, K.A. : Surface coatings on dental cementum incident to periodontal disease, II. Scanning electron microscopic confirmation of a mineralized cuticle. J. Clin. Periodontol., 11 : 565-575, 1984.

15) Hughes, F.J. and Smales, F.C. : Immunohistochemical investigation of the presence and distribution of cementum -associated lipopoly-saccharides in periodontal disease. J. Periodont. Res., 21 : 660-667, 1986.

16）西村和晃, 高田耕平, 野口吉広, 永石真幸, 林 正 純, 白井義英, 山田 実, 山口十紀夫, 山岡 昭 : 歯肉剝離搔爬手術後の新付着に関する研究（第 7 報). 一污染セメント質に関する電子顕微鏡的観 察一。日歯周誌, $27: 846-855,1985$.

17) Cole, R.T., Crigger, M., Bogle, G., Egelberg, J. and Selvig, K.A. : Connective tissue regeneration to periodontally diseased teeth. A histological study. J. Periodont. Res., 15 : 1-9,
1980.

18) Albair, W.B., Cobb, C.M. and Killoy, W.J. : Connective tissue attachment to periodontally diseased roots after citric acid demineralization. J. Periodontol., 53 : 515-526, 1982.

19）西村和晃, 高田耕平, 野口吉廣, 道家浩之介, 英 保武志, 中西 徹, 山口十紀夫, 山岡 昭: 歯肉 剝離搔爬手術後の新付着に関する研究. 一根面処 置法に対する付着について (2). 日歯周誌， 28 : 924-925, 1986.

20) Daly, C.G. : Anti-bacterial effect of citric acid treatment of periodontally diseased root surfaces in vitro. J. Clin. Periodontol., 9 : 386-392, 1982.

21) Fine, D.H., Morris, M.L., Tabak, L. and Cole, J.D. : Preliminary characterization of material eluted from the roots of periodontally diseased teeth. J. Periodont. Res., $15:$ 10-19, 1980.

22) Register, A.A.: Human pocket reattachment to root dentin, demineralized in situ. J. Dent. Res., 54 (special issue A) : 64, 1975.

23) Register, A.A. and Burdick, F.A. : Accelerated reattachment with cementogenesis to dentin, demineralized in situ. 1. Optimum range. J. Periodontol., 46 : 646-655, 1975.

24) Register, A.A. and Burdick, F.A. : Accelerated reattachment with cementogenesis to dentin, demineralized in situ. 2. Defect repair. J. Periodontol., 47 : 497-505, 1976.

25) Crigger, M., Bogle, G., Nilvéus, R., Egelberg, J. and Selvig, K.A. : The effect of topical citric acid application on the healing of experimental furcation defects in dogs. J. Periodont. Res., 13 : 538-549, 1978.

26) Ririe, C.M., Crigger, M. and Selvig, K.A. : Healing of periodontal connective tissues following surgical wounding and application of citric acid in dogs. J. Periodont. Res., 15 : 314327, 1980.

27) Polson, A.M. and Proye, M.P. : Fibrin linkage : A precursor for new attachment. J. Periodontol., 54 : 141-147, 1983.

28) Stahl, S.S. and Froum, S.J. : Human clinical and histologic repair responses following the 
use of citric acid in periodontal therapy. J. Periodontol., 48 : 261-266, 1977.

29) Kashani, H.G., Magner, A.W. and Stahl, S.S. : The effect of root planing and citric acid applications on flap healing in humans. A histologic evaluation. J. Periodontol., 55 : 679-683, 1984.

30）西村和晃，野口吉広，永石真幸，林 正純，山田 実, 中谷 聡, 山岡 昭 : 歯肉剝離搔爬手術後の 新付着に関する研究 (第 11 報). 一表層一層搔爬 セメント質に対する剝離歯肉弁の初期付着につい て一. J. Clin. Electron Microscopy., 20 : 53-61, 1987.

31）西村和晃, 野口吉広, 永石真幸, 林 正純, 山口 十紀夫, 山岡 昭 : 歯肉剝離搔爬手術後の新付着 に関する研究 (第 10 報). 一クエン酸脱灰露出線 維に対する剝離歯肉弁の初期付着について一. J. Clin. Electron Microscopy., 19 : 237-244, 1986.

32) López, N.J. : Connective tissue regeneration to periodontally diseased roots, planed and conditioned with citric acid and implanted into the oral mucosa. J. Periodontol., 55 : 381-390, 1984.

33) Aukhil, I., Greco, G., Suggs, C. and Torney, D. : Root resorption potentials of granulation tissue from bone and flap connective tissue. J. Periodont. Res., 21 : 531-542, 1986.

34) Aukhil, I., Suggs, C. and Pettersson, E. : Healing following implantation of partiallydemineralized roots in palatal connective tissue. J. Periodont. Res., 21 : 569-575, 1986.

35) Pitaru, S., Gray, A., Aubin, J.E. and Melcher, A.H. : The influence of the morphological and chemical nature of dental surfaces on the migration, attachment, and orientation of human gingival fibroblasts in vitro. J. Periodont. Res., 19 : 408-418, 1984.

36) Pitaru, S. and Melcher, A.H. : Organization of an oriented fiber system in vitro by human gingival fibroblasts attached to dental tissue : Relationship between cells and mineralized and demineralized tissue. J. Periodont. Res., $22: 6-13,1987$.

37) Preisig, E. and Schroeder, H.E. : Longterm culture of human periodontal ligament cells with autologous root discs. J. Periodont. Res., 23 : 211-221, 1988.

38) Nishimura, K. and Aukhil, I. : Matrix synthesis by HGF on dentin and cementum surfaces. J. Dent. Res., 68 (special issue) : 362, 1989.

39) Nishimura, K., Hayashi, M., Matsuda, K., Shigeyama, Y., Yamasaki, A. and Yamaoka, A. : The chemoattractive potency of periodontal ligament, cementum and dentin for human gingival fibroblasts. J. Periodont. Res., 24 : 146-148, 1989.

40) Somerman, M.J., Archer, S.Y., Foster, R.A. and Hassell, T.M. : Extracts of mineralized tissue enhance protein production by human gingival fibroblasts in vitro. J. Dent. Res., 64 (special issue) : 217, 1985.

41) Somerman, M.J., Archer, S.Y., Shteyer, A. and Foster, R.A. : Protein production by human gingival fibroblasts is enhanced by guanidine EDTA extracts of cementum. J. Periodont. Res., 22 : 75-77, 1987.

42) Somerman, M.J., Perez-Mera, M., Merkhofer, R.M. and Foster, R.A. : In vitro evaluation of oxtracts of mineralized tissues for their application in attachment of fibrous tissue. J. Periodontol., 58 : 349-351, 1987.

43) Somerman, M.J., Foster, R.A., Imm, G.M., Sauk, J.J. and Archer, S.Y. : Periodontal ligament cells and gingival fibroblasts respond differently to attachment factors in vitro. $\mathrm{J}$. Periodontol., 60 : 73-77, 1989. 


\section{Legends}

Fig. 2

Micrographs of the curetted cementum treated with citric acid one week postoperatively. a :

A few inflammatory cells infiltrating into the connective tissue underlying the junctional epithelium and lateral extension of the junctional epithelium into the connective tissue are seen. Note the apical end of the junctional epithelium (arrowhead) located on the enamel surface.

b :

In the zone immediately beneath the junctional epithelium, granulation tissue is interposed between the lightly stained demineralized cementum and the replaced gingival tissue. c :

Electron micrograph of the zone immediately beneath the junctional epithelium, in which an inactive fibroblast $(\mathrm{Fb})$ with less $\mathrm{r}$-ER and fewer Golgi-complexes is aligned parallel to the demineralized cementum (DC). No newly formed collagen material is seen between the exposed cement fibrils and the fibroblast.

$\mathrm{d}$ :

In a more apical portion, granulation tissue with greater cell density covers the demineralized cement surface. Note fibroblasts extending into the demineralized cementum.

e :

Electron micrograph of the zone in Fig. 2-d. The fibroblast $(\mathrm{Fb})$ with well developed $r$-ER, euchromatic nucleus and numerous free ribosomes appears among exposed cement fibrils, resulting in newly formed collagen materials between the fibroblast and the exposed cement fibrils.

Fig. 3

Micrographs of the curetted cementum treated with citric acid two weeks postoperatively. a :

A few inflammatory cells have infiltrated into the connective tissue underlying the junctional epithelium. The junctional epithelium has migrated apically along the undemineralized cementum. Note the apical end of the junctional epithelium (arrowhead) located on the coronal border of demineralized cementum.

b :

In the zone beneath the junctional epithelium, granulation tissue appears to be more fibrous after two weeks than after just one week, and the cells in the granulation tissue are oriented in parallel adjacent to the demineralized cementum. Note the junction between the new and old tissues.

c :

Electron micrograph of the zone in Fig. 3-b. Newly formed collagen fibrils showing typical periodicity have formed between the fibroblast $(\mathrm{Fb})$ and the demineralized cementum (DC).

Note collagen fibrils (arrows) inserted perpendicularly into the exposed cement fibrils.

\section{Fig. 4}

Micrographs of curetted cementum without citric acid application two weeks postoperatively. a :

The junctional epithelium is located on the coronal portion just as in the sites to which citric acid was applied.

b :

Newly formed collagen fibers are inserted perpendicularly into the cementum, i.e., a new fibrous attachment has been reestablished. Note resorption lacunae on the cement surface.

Fig. 5

Micrograph of the curetted cementum treated with citric acid three weeks postoperatively.

Newly formed collagen fibrils (NCf) have formed between the demineralized cementum (DC) and the fibroblasts $(\mathrm{Fb})$ adjacent to them after three weeks rather than after one or two weeks. Note the interdigitation of exposed cement fibrils with newly formed collagen fibrils. 



Fig. 2 

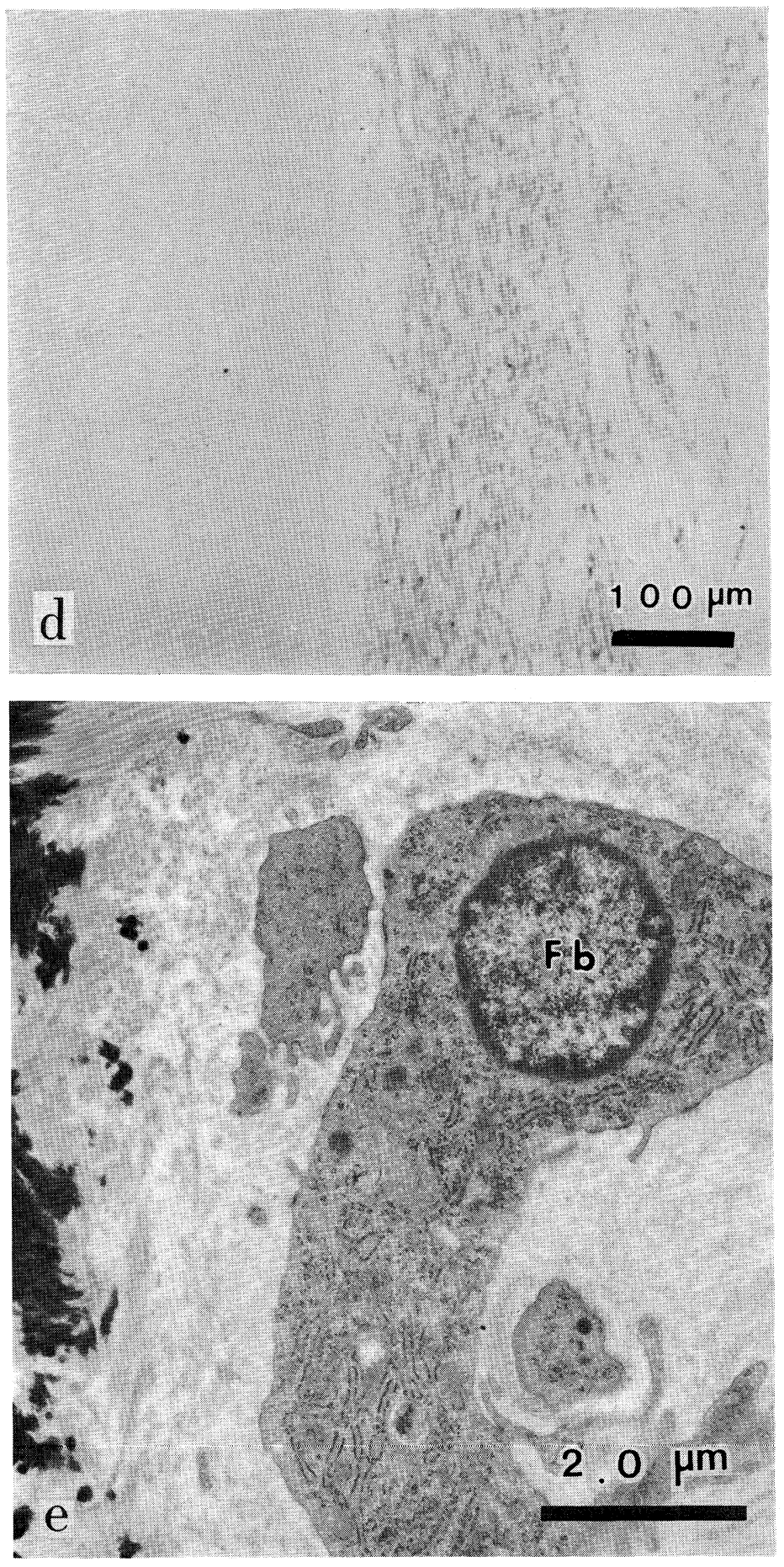

Fig. 2 つづき 

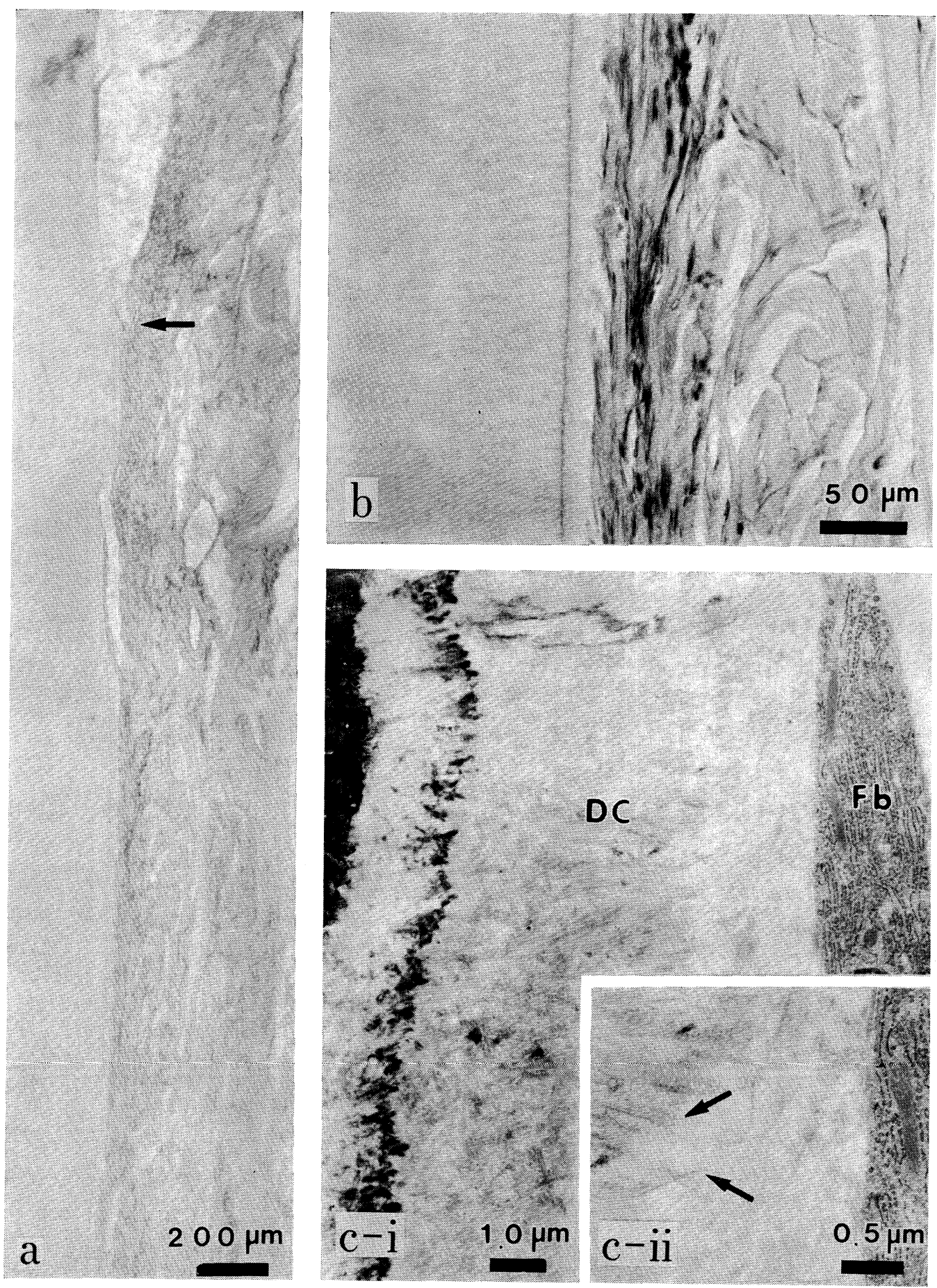

Fig. 3 

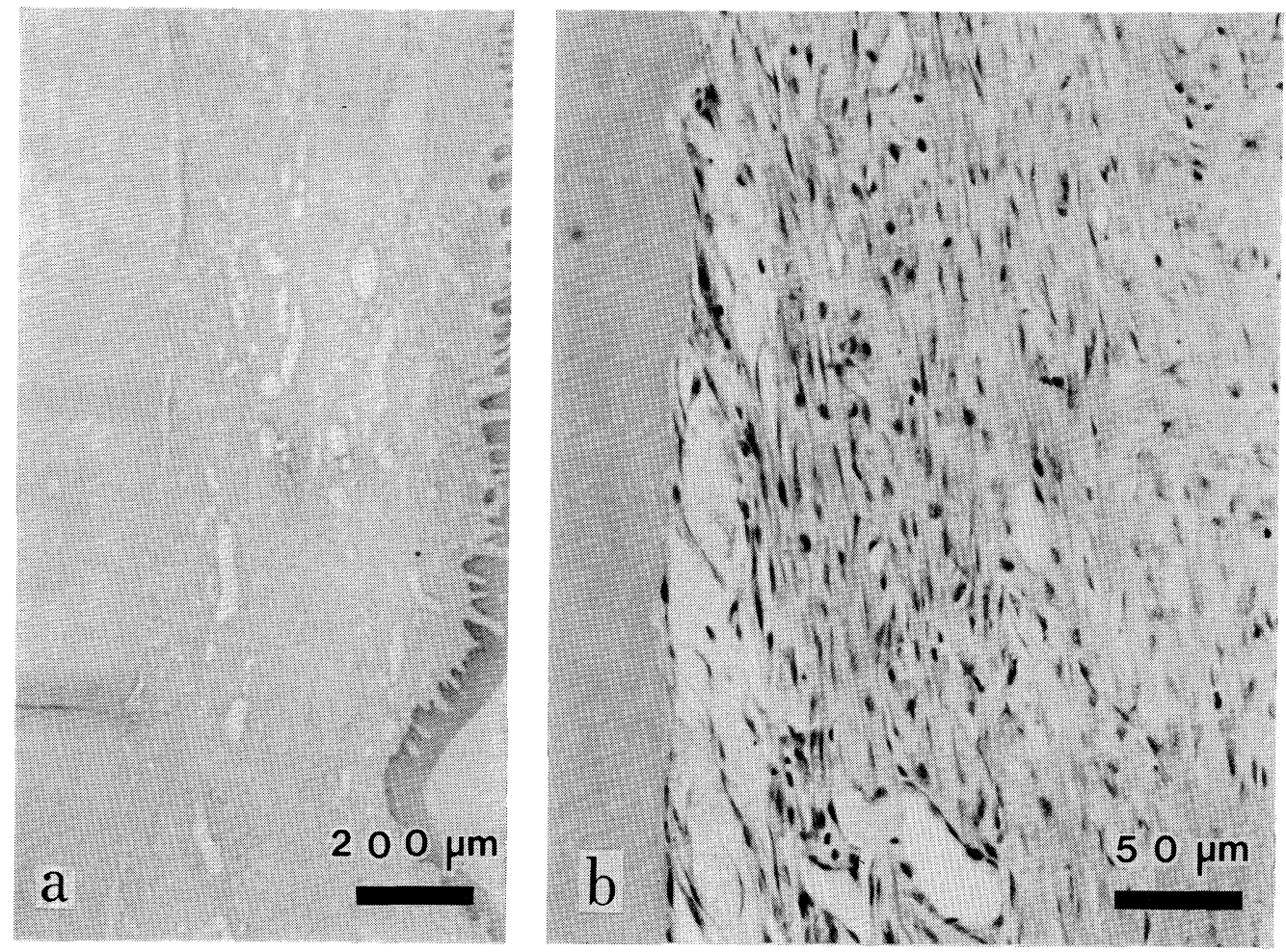

Fig. 4

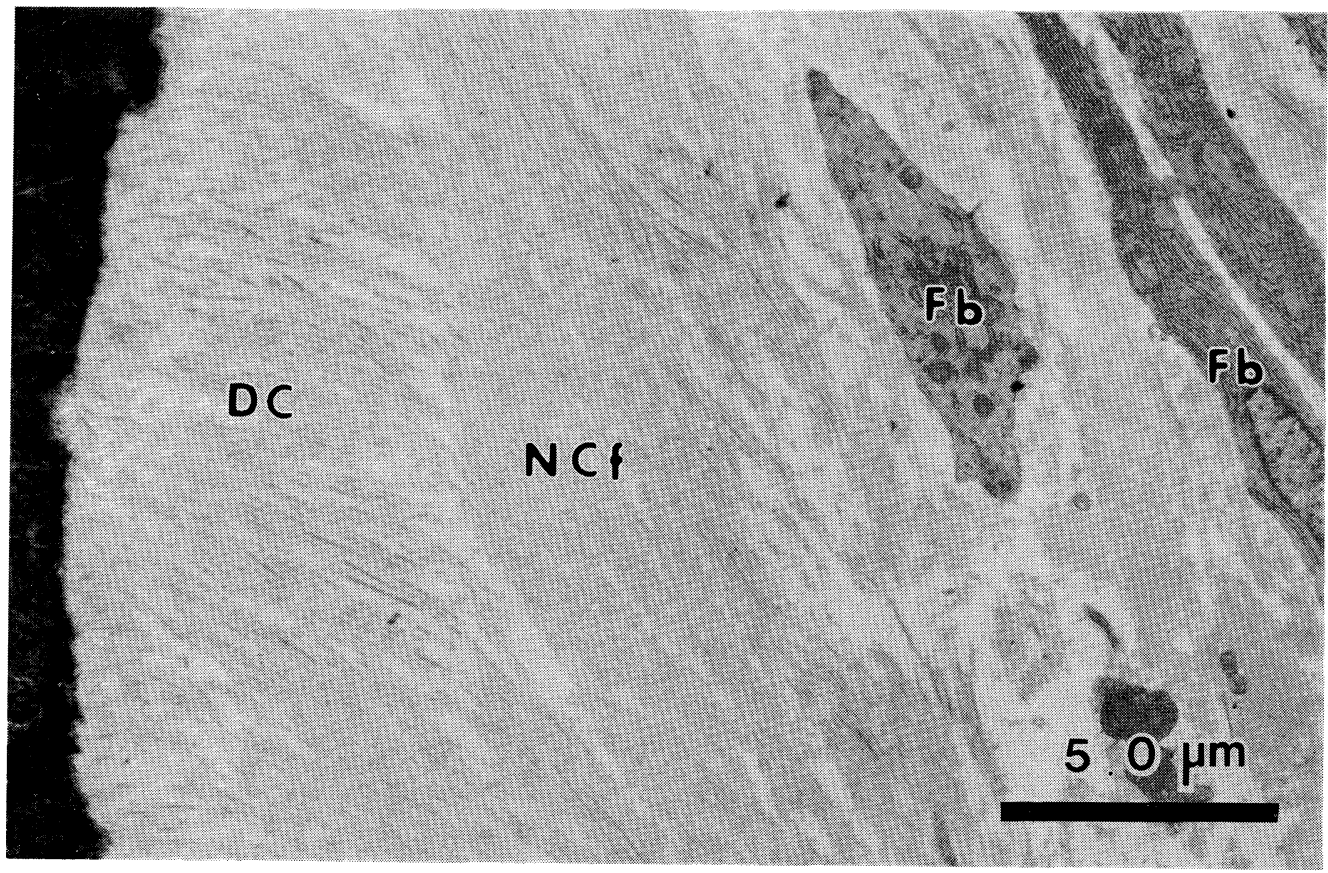

Fig. 5 